\title{
The Current Political Path of an Ultra-Catholic Agent of Brazilian Christofacism Father Paulo Ricardo
}

\author{
Fabio Py ${ }^{1}$ D \\ Received: 3 May 2021 / Accepted: 3 August 2021 / Published online: 30 August 2021 \\ (c) The Author(s), under exclusive licence to Springer Nature Switzerland AG 2021
}

\begin{abstract}
The article foregrounds Father Paulo Ricardo's role in the political history of the present time and in the building of the political-religious guidelines that helped the shaping and mobilization of Jair Bolsonaro's extreme rightwing project, from 2018's candidacy to the presidency, but mainly in the face of time management of the Covid-19 pandemic. From the notion of Christofascism, as a "theology of authoritarian power," one seeks to understand how the referred priest helps in intellectual production, hence sustaining the governmental summit mainly with the arrival of Covid-19 in the country. The article also seeks to use the notion of "trajectory" by Giovanni Levi to trace the last years of the priest's religious activity, mainly from his productions on social media of political-religious appeal, when Father Paulo Ricardo directly feeds what we call Bolsonaro's "Christofascism" with themes that help in the "war of the gods" promoted in this condition, in contempt for science and helping to feed this new type of authoritarianism experienced in contemporary Brazil.
\end{abstract}

Keywords Father Paulo Ricardo $\cdot$ History of the present time $\cdot$ Political-religious · Christofascism - Theology of Authoritarian Power

\section{Introduction}

The government of Jair Messias Bolsonaro is fasten upon a dense cloud of religious actors and hegemonic Christianities, which support the scope of his state management, reinforced by ultraconservative Christianity and the denial of science. The

Fabio Py

pymurta@gmail.com

1 Faculty of the Graduate Program in Social Policies, North Fluminense State University (UENF), Rio de Janeiro, Brazil 
historiography of the present time (Teixeira da Silva 2020a, b), which the Brazilian State has been dealing since 2019, has become an example of "necropolitical machinery". 1

In order to implement this state of necropolitical practice, different forms of Christianity have been helping this weaving management, by its turn, at least, present themselves in three theological realms: the first addressing the Pentecostals linked to Prosperity Theology, filling the government's discourse with daily expressions of faith such as "blessings" and "victories" (Py 2020a, b); the second, the traditional Protestants (mainly Baptists and Presbyterians) who sprinkle Bolsonaro with theological themes of the type "elected to govern the nation"; and the third, the oldest, which is structured as the backbone of the country, conservative Catholicism.

It is mentioned in the article the branch of Conservative Catholicism, directly supported by Bolsonaro (2020a, b), irrigated by at least two more prominent sources related to Bolsonarism, the traditional Catholics and the charismatic Catholics group, from the Catholic Charismatic Renewal (CCR). Then, in order to deal with this primordial realm of Bolsonaro's administration, we have selected a fundamental life trajectory for Catholicism in the actuality: Father Paulo Ricardo. Hence, the article seeks to highlight the priest's latest events from Giovani Levi (1996)'s microhistory, to rebuilding his individual trajectory in the "involvement with bankruptcies, bonds and expelling from social and religious sectors" (1996, 175-184).

With the Italian historian's concept, we seek to capture his social plots, his political involvement with State elites, and "the continuities that cross the ideology of the rulers and political thought" (Rémond 1999, 54). From this New Political History, we derived, from the public persona of Paulo Ricardo, in order to trace "the pathway of less extraordinary people (...) who are linked to contexts much larger than just their actions and their lives" (Lévy 1999, 179). So his pathway will be described from "his activities on the Internet, as sources of positioning expressions, the experiences and the history of people in its own times, through the social networks," as indicated by Denis Rolland (2004). It's from Rolland that is sought "the description of people's activities on the internet as historiographical sources with specific characteristics, even, with a wide impact domain of this material" (Rolland 2004, 71).

Consequently, based on the belief of "individual trajectory" by Giovani Levi as well as on the "mapping of internet production" indicated by Denis Rolland (2004, 75), a short "political action" history will be highlighted (Rosanvallon 2015) of father Paulo Ricardo. As the "political action" term by Pierre Rosannvallon indicates, since "participation in strikes or manifestations, or the signing of petitions, the expression of collective forms of solidarity" (Rosanvallon 2015, 55). That is, for the French historian, there is a new configuration of the "political action by changing, not a decline of citizenship, with the diversification of their repertoires and targets." As indicated, facing the crisis of the "main institutions of representation and negotiation decreasing, different organizations then are multiplied, giving citizens other ways to express their complaints" (Rosanvallon 2015, 57).

\footnotetext{
1 Who uses the term is Mbembe (2014), by emphasizing that "modern states have become constant ways of generating deaths of the undesirable" (p.19).
} 
Thus, it is assumed in the article that each "media scene" of Father Paulo Ricardo is a "political action" by "different joint vectors of spraying in the social affirmation and distension body in relation to the political status" (Rosanvallon 2015, 61). Each action-scene of the priest would be at the same time a tip of the "War of the Gods" (Lowy 2000) of great importance of the Bolsonarist State. That is so because the priest is a "media impact persona" (Lévy 1999) tuned into multiple social networks and sites, collecting thousands of followers.

So, the priest crosses through both Catholic worlds presenting a vast academic background with visits to institutions in the USA and Italy, through his pastoral practice inserted into the ecclesiastical structures of Mato Grosso. Now, in addition to these data, he is recurrently quoted on social networks (Bolsonaro 2020a, b) by Bolsonaro's summit, serving ideologically the persecutory mentality of Brazilian Sate's summit. The article is divided into two parts: the first part the intention is to conceptualize the Christofascism of Bolsonaro's administration; and the second one will be spread into two points- the first will be a priest short biography, and the second is an outline of his political and religious trajectory bringing his political biased posts on social networks since 2013. The objective is to show how the religious bias assemble political actions, paving Bolsonaro's political hegemony. Therefore, shortly before dealing with his persona, we will indicate what is defined as "Christofascism" or "Brazilian Christofascism."

\section{Bolsonaro's Brazilian Christofascism and His Theological Intellectuals}

To call attention to the Messiahship' "political architecture" (Rosanvallon 2015) formed by Bolsonaro's governmental summit, based on the performance of "organic intellectuals" (Gramsci 1982) such as Father Paulo Ricardo, Silas Malafaia, Edir Macedo and Josué Valandro Junior, some conceptual elements stand out about what has been called "Brazilian Christofascism" (Py 2020a). The hegemonic Christianity used today by Bolsonarism, formulated by theological intellectuals, is promoted in the context of an "authoritarian political theology that escalates and shapes the State" (Schmitt 1988, 21). This political theology is guided by the reading and interpretation of the "Great Christian Missionary Institutions," solidifying a political of "hatred for democratic plurality" (Teixeira da Silva 2020a, b).

The Bolsonaro government has its hatred toned "for the theological governmental techniques" (Schmitt 1988, 21) of promoting discrimination in relation to the "heterodox" sectors (Bolsonaro 2020a, b; Py 2020a). What has already been seen in the coronavirus expansion in Brazil, which amplified its perpetual anti-democratic appeal with economic impetus that justifies the "death policy" ("necropolitics"Mbembe 2014; Butler 2004)_against the poorest sectors of the population, the elders, diabetic people, and hypertensive patients (Bolsonaro 2020a, b).

The catchword "Brazilian Christofascism" derives from Dorothee Sölle's (1970) expression Christofascism, created by her from the recollection of German Nazism, especially of Auschwitz, in his: "Beyond Mere Obedience: Reflections on a Christian Ethic for the Future" ( 1970). Sölle's term is concerned in pointing out 
"the relations of members of the Nationalsozialistische Deutsche Arbeiterpartei (NSDAP - the Nazi party) with Christian churches in the development of the state" (Sölle 1970).

With this definition in mind, Sölle demonstrates that the Nazi government used Christian relations and terminologies for its social cohesion, as Bolsonaro's government does it now. ${ }^{2}$ Hitler also had used Christian quotes, planned in the most detail accuracy, as the one that says "You will know the truth and the truth will set you free," quoted by the Book of John 8:32 and also "Created God, man in his image; in the image of God he created him; man and woman created them" (Sölle 1970)_in order to defend the traditional German Christian family. The Führer made crusades in Christian meetings (Lutherans, Catholics and confessionals), relating himself to pastors and priests, and among the Lutherans some pastors had stood out, as per Walter Hoff, Rudolf Kittel, and Prospt Ernst Szymanowski, developers of the socalled "positive Christianity" (Sölle 1970), so important for the Führer and who took care of specialized theological production, such as the case of Father Paulo Ricardo today in the Bolsonaro's administration.

In her book (1970), Sölle points out that white extremists in the USA would have the same "attitude of hatred, prejudice and racism" (Sölle 1970) previously seen in the Nazi imperial regime. When describing fundamentalist groups on American soil, she uses the term "cristofascism" (Sölle 1970) as a direct action of white supremacist groups in the USA, not relating to the State but to a "political culture" (Rémond 1999) in a such straightforward way. Sölle was not concerned with the connection of Christofascism as "an authoritarian political theology that supports states, governance, elites" (Schmitt 1988, 24). She points it out with the theological sense of "blind obedience," when "in relations with the Divine of people in authoritarian regimes or in fundamentalist groups" (Sölle 1970, 65).

Sölle considers the "deepening of the unilateral understanding of Christianity (...) in the Second World War and in the Americans by the context of the extremist violence of Christian fundamentalists" (Sölle 1970). Hence, for her, Christofascism is a characteristic theology "of the Church in Germany under Nazism, and still alive at the end of the twentieth century in the extremist white groups" (Sölle 1970) in the USA. By this expression, Sölle believes that it's a "deviation from fundamentalist Christianity in the service of white and patriarchal supremacist, which extends through the spread of fear, punches, misogyny and structural racism" (Sölle 1970, 67).

Therefore, due to the Sölle's narrative strength, it is believed that in the South hemisphere, another modality of Christofascism has been developed: "the Brazilian" (Py 2020b). This new type would build a connection between extremists Christian groups altogether with "political actions" (Rosanvallon 2015), shaping State practices of Bolsonaro's government. In this sense, as Brazilian Christofascism, it is more concerned with clothing than to what Carl Schmitt has called the "architecture of governmental power" (Schmitt 1988), meaning, "in the shading of States that are

\footnotetext{
2 Bolsonaro's most important speeches (those broadcasted on the national network) evoke Christianity, as for example, when quoting Bible verses or making use of Christian greetings (Bolsonaro 2020a; b).
} 
concerned with meaning of power from the social groups and the authority of the divine governor, for the government with authoritarian theological imaginations" (Schmitt 1988, 26). Thus, the concern is not only with the descriptions of fundamentalist movements as Sölle had stated.

In "Political Theology" (1988) Carl Schmitt understands "the architecture of authoritarian power" being inspired by hegemonic monotheistic religions, in the Brazilian case, Christianity. From Schmitt's (1988) approach, it is understandable that Bolsonaro's government is fed by a theological flow from a chain of intellectuals triggered by presidential management. Therefore, in the article, Paulo Ricardo stands out, as one of those intellectuals, who feeds the current ones with sermons, messages, and images anchored in a medieval theology of "Christ-King, also, of the God-legislator as a human jurist—-the sovereign—of the of the State"(Schmitt 1988, 27).

Also, it's worth mentioning that when it comes to this Brazilian approach, in which it is called cristofascismo, the concern is to think about fascism from Benjamin (2013), recognizing it as barbarism of authoritarian fascination that does not represent an internship of "civilizational regression, but it is contained in the very conditions of reproduction of liberal-bourgeois civilization" (Gagnebin 2014, 142). Thus, fascism is recognized as a political machinery for constituting the "state of exception" (Benjamin 2013), a part of the steamroller that migrated from the governmental techniques that dominated the colonies applied by Europe and the North (Benjamin 2013) and today that is the foundation of global capitalism.

Fascism would also be the "liberation of the destructive forces produced by a bourgeois civilization in crisis in order to keep the accumulation process in operation, the capitalism" (Benjamin 2013, 94). The philosopher conceives that the fascination imposed by the authoritarian government fits together with conservative conceptions of moral values, family and progress, to operate the transformation of all nation into an "effective state of exception" (Gagnebin 2014, 154). The fascistm management, or neo-fascist for Löwy (2020), determines a "disciplining action of the proletarianized masses, thereby avoiding any disturbance to the property regime.

It is a matter of allowing such masses to express themselves as masses, as long as it doesn't challenge the established order, putting in check any claims that touch the social structure as it is" (Benjamin 2013, 211). It is stated that Bolsonaro's government and its "theology of state power" (Schmitt 1988) are projected from the ultraconservative Christianity (Zeferino and Andrade 2020), by which it assumes the "notion of the Brazilian Christian family to in order to promote the elimination of their opponents and of the undesirable ones" (Py 2020a), in this case, under the context of Covid-19, those who don't fit the healthy range. ${ }^{3}$

Hence, the last theoretical detail about the notion of cristofascism is displayed in the text. It operates politically a "War of the Gods," a term by Michael Löwy (2000), resignified from Max Weber's work "Science as a vocation" (1919). By this concept, Löwy (2000) points out that the conflicts over "the polytheism of values and the

\footnotetext{
3 A deepening of the necropolitics of Mbembe (2014) has been occurring in Brazil, in this case, in the face of the "low healthy ones".
} 
insoluble conflict of the basic beliefs are 'gods' into modern society" (Weber, 1998, p.18). Also the different disputes of all religious narratives that arrive at the State' political instances are recognized. Then, it shows that the term:

first (...) it applies to the conflict in the religious field between radically opposed conceptions of God: that of progressive Christians and that of conservative Christians (both Catholic and Protestant) - a 'coalition of values' (Wertkollision - another Weberian term) that, in extreme situations such as that of Latin America in the 1980s, it can even be transformed into a civil war (Lowy 2000: 18).

Löwy understands that in Latin American societies "there is a real war of gods," that is, between "various conceptions of gods as a symptom of the social struggles between civil societies and the states" (Lowy 2000: 15). Hence, it is said that Bolsonarism, based on its theological intellectuals such as Paulo Ricardo, operates a sequence of political actions (Rosanvallon 2015) of "war of the gods," sometimes simplifying, sometimes projecting a fascination of the presidential figure with the Christian messianic concept. This operation is very well designed by the intellectual body close to the government who draw the presidential figure as a political messiah, placing him as a "savior of the country, established in Jesus" (Paulo Ricardo 2018), or even as a suffering, anointed servant and elected from the nation in the context of the Covid-19 pandemic in Brazil.

Brazilian Christofacism has been politically influencing the southern territories as, for example, more recently it has been shaped by the new government modulations in Bolivia. I quote the conservative Christian coalition that has the figure of Jeanine Añez, interim president, in which, in the face of a coup, she signaled that the Bolivian "Bible has returned to the palace." Although this phenomenon will not be analyzed here, it is noteworthy that other authoritarian governments sprout South America, supported by Christian speeches and intellectuals, for the implementation of ultraliberal agendas. ${ }^{4}$ This phenomenon is coupled in a modality called "Southern Christofascism." After these signs, we move on to a short biography (Bourdieu 1996) of the ultra-Catholic priest, Paulo Ricardo, and then, based on his intellectual production (with six posts), we will indicate how it has been an important politicalreligious base of the current presidential administration.

\section{Who is Father Paulo Ricardo?}

Father Paulo Ricardo is called Paulo Ricardo de Azevedo Júnior, attached to the Archdiocese of Cuiabá, Mato Grosso. He was born in Recife (PE) in 1967, and in 1979 he traveled with his family to Cuiabá. Between 1983 and 1984, he did an exchange High School Program and graduated in Michigan, USA, where he was influenced by books and ambiences of American conservative Catholicisms (Silveira

\footnotetext{
${ }^{4}$ Jose Tamayo (2020), who took on a job close to this comparison, when he supports the notion of "Christoneofascisms," based on a transnational expansion of hatred of pluralities, comparing the growth of rights in the last years in the world based on ultraconservative Christian guidelines.
} 
2019, 289-309). The contact has helped to shape the decision to enter the Seminary in 1985 and, in 1992, becoming a priest, with a background in philosophy and theology. He defended his master's degree in Canon Law at the Pontifical Gregorian University, in Rome, in 1993 (Silveira 2019, 289-309).

His educational formation was between the pontificates of John Paul II and Benedict XVI, extremely conservative considering the dialogue between faith and the contemporary world. Currently, the priest exercises functions related to pastoral and teaching in colleges and parishes: Vicar Parish in Cuiabá, Rector of the Cristo Rei Seminary, Secretary General of the Archdiocesan Synod of Cuiabá, Professor of Philosophy and Psychology at the Catholic University Dom Bosco, at the Regional Institute of Theology and at the Studium Ecclesiastical Dom Aquino Corrêa-Campo Grande and Cuiabá (Silveira 2019).

Paulo Ricardo connects himself with ultraconservative Catholic thought, tensioning other Christian traditions, especially those of Afro-Diaspora matrix. He has dedicated to write books and presents the weekly program, "Oitavo Dia," by Rede Canção Nova Broadcast. It adds a large amount of services on its website, charging for videos and classes (Silveira 2019). His activities are widespread on the Internet, being the Brazilian priest with greatest impact on the web. The maintenance of his educational institute in Cuiabá is possible from the courses he teaches over the Internet. Every service on the websites is handled by a team called Christo Nihil Praeponere, which means in Latin: "To give nothing more value than Christ"-his "visual identity" (Silveira 2019, 289-309).

Many YouTube videos prohibit the insertion of comments, thus making it difficult to propagate controversies and make negative comments visible, in addition to each video having a brief explanatory comment summarizing the central idea of the speech or the conference (Silveira 2019). Most of the priest's posts are self-referential. The priest's immense activity as a teacher and lecturer is contained in electronic social networks, which amplifies his opportunities to participate in mass events and presents a TV program in Canção Nova Broadcast Community (Silveira 2019).

This activity has gained such proportions that, per example, the news "Diário de Cuiabá" published a report against the priest's performance, entitled "Priests ask the bishop that Father Paulo be silenced. In a letter addressed to the archbishop, 27 priests have asked that the priest be prohibited from preaching" (Silveira 2019, 300). However, the text indicates that there was a radical support from the catholics faithful to the priest. On the other hand, it is possible to highlight his constant performance in Congress with professedly Catholic and evangelical politicians. In the end, the sum of controversies has helped to mobilize, as they are disseminated by the religious media, giving the priest more exposure and propaganda, all with the consent of the diocesan bishop, Dom Milton Santos (Silveira 2019).

Emerson Sena Silveira indicates that "the support received from thousands of faithful believers also comes from his discursive resourcefulness, feeding back his profile and websites, in a continuous movement" $(2019,301)$. This circuit benefits the construction of an intense "war of the gods" (Lowy 2000) traced in the restrictive reading of the Catholic tradition against those who threaten the "traditional Brazilian Christian family," as defended by the Evangelical Parliamentary Front (Py 2020b) - ultraconservative tentacle that often summons him for lectures. 
With this emblematic persona of Brazilian ultraconservatism being introduced, a "mapping of his emblematic productions of social networks" is presented (Rolland 2004, 75-79), in this case six "media productions with wide internet circulation" (Lévy 1999) in which they show the "political actions" direction (Rosanvallon 2015) in support of Bolsonaro's rise and supporting his management.

\section{Trajectory of Father Paulo Ricardo's Political Action}

From this point, we will describe six "political actions" built by Father Paulo Ricardo through social media, which "focus on the social dynamics amplification, from the diversification of his repertoires and diversification of political targets" (Rosanvallon 2015, 61). They are part of the "internet produced scenes/productions" (Rolland 2004, 73) of the priest "because, today, they are essential parts to understand the messages and social objectives" (Lévy 1999, 76) while political-religious articulator of the rise of Bolsonarism.

\section{The Roman Catholic Church Is Not Peaceful}

Then, the first "political action" selected by the priest is over the issue of firearm liberalization in the country, a central agenda of Bolsonaro, from the first moments of his political activity. In the video "The church and disarmament," still in 2011, he states that "the plebiscite was to take legal weapons out of the hands of Brazilians (...) Well, in a superficial approach, you can take the catechism about war, and you will find there very juicy paragraphs in hand, those who are in favor of disarmament (...) The church is in favor of disarmament. Wrong, red light for you" (Paulo Ricardo 2011).

In 2011, Jair Bolsonaro was already a Federal Deputy for the Progressives Party and started to build arguments for the liberation of the possession of weapons (Teixeira da Silva 2020a, b; Almeida 2019). Then, Father Paulo Ricardo produces the material in line with Bolsonaro's guidelines, after his first contacts with Bolsonaro family, that took place in Araraquara in 2011 (Almeida 2019), indicating that the church is not against the armament of the population. The church, in the "very specific context of the arms race (...), is in favor of reducing these so lethal weapons, weapons of mass destruction (...) Let us understand my brother: the Christian is peaceful, not pacifist" (Paulo Ricardo 2011).

He weaves the argument in favor of arming the population from the extreme case of invasion of properties: "it is a duty, a burglar who enters your home, rapes your daughter, rapes your wife, squanders your assets, what will you do ? Will you say you are for peace? You will have courage to look at your daughter, your wife, and look: I did nothing not because I am a coward, but because I am a pacifist" (Paulo Ricardo 2011).

The priest in the political action grasps the case to substantiate the population's right to access to weapons. In the same tone as Bolsonaro's speech in January 2011, at the Hebrew Association of Rio de Janeiro (Almeida 2019), the priest develops his 
reasoning by tracing a relationship between firearms, middle class security, private property, and the defense of family (Paulo Ricardo 2011). In the video, the priest indicates that the Catholic Church is against weapons of mass extermination, but not against individual firearms (Paulo Ricardo 2011).

It's interesting to say that the priest's video was so popularly commented that the Bolsonaro clan (Bolsonaro 2020a, b) reposted it on social media a few times, thus helping to reaffirm the presidential argument from Christian vestments: "weaponize the population (...) in order to be truly free" (Bolsonaro 2020a). The priest's political position is valuable for the construction of Bolsonaro's political mandates, helping him in the defense of arming the population, as he said: "arming the population is a sign of freedom for the personal defense of each individual" (Bolsonaro 2020a).

\section{The Stabbing and the Persecution of Bolsonaro in 2018}

The second political action (Rosanvallon 2015), in the form of an "internet scene" (Rolland 2004), took place in the context of the 2018 presidential elections, when the priest taught some courses in the parishes (Silveira 2019). In one of these courses, he again indicated his connection with Bolsonaro's project, when he directly cited the stabbing that the then candidate suffered during the elections. The material was recorded in the form of the video "Father Paulo Ricardo pronounces himself on the attack against Bolsonaro and the video goes viral on the web" (Paulo Ricardo 2018), on September 11, 2018. The video is a short but elucidative material. In a few words, you can see the priest saying: "How do you shut people up? Or you go and stab ... (the audience says: myth! Myth! Myth!)".

The video shows the support of the audience and the priest to Bolsonaro; when speaking at the parish, he does not ask people to calm down in the face of the quote to what has happened to the candidate (Paulo Ricardo 2018; Py 2020a). The statement indicates that the stab suffered by Bolsonaro in the scope of the 2018 elections was an attempt to "silence" the candidate, emphasizing a "war against the presidential candidate" (Paulo Ricardo 2018) in the country in 2018. He aims to boost the video giving symbolic strength to the violence against Bolsonaro. The father seeks to draw Bolsonaro as a martyr, a typical element of Christianity: the evocation of the persecutions suffered by Christians since the emergence of Christianity in the context of Ancient Rome (Paulo Ricardo 2018; Boff 1974).

So, in the video sequence, the priest remembers a pope that represents the conservative Catholicism, Benedict XVI. He says, "whether you do what Benedict XVI calls 'martyrdom of modern times,' which is to slander, discredit, make up lies about these people" (Paulo Ricardo 2018). Therefore, based on the tone of adhesion to Bolsonaro with the ultra-Catholic vocabulary, it indicates that they try to produce lies that aim to discredit Bolsonaro, building over the candidate a "martyrdom of modern times" (Paulo Ricardo 2018), by political persecution of Bolsonaro.

The video encourages the construction of the persecutory mentality that is falling on Bolsonaro's political trajectory, deepened in his presidential management (Teixeira da Silva 2020a, b). Therefore, the material in video form develops a common logic in the most conservative branch of Christianity that evokes the 
centrality of "via crucis as a paradigmatic path for true Christians" (Boff 1974, 63). Also, there is the dimension implicit in the tone of Father Paulo Ricardo's statements, signaling that just like "Jesus, God and savior, he suffered in this world for our sins, to save us" (Boff 1974, 65), the candidate Jair Bolsonaro has a salvation project — the salvation of the nation (Paulo Ricardo 2018).

With the video, from the time of the elections, the religious man implies that there is an operation to transform ultraconservative Catholicism from the figure of Bolsonaro into a Christian martyr. Indicating him as someone persecuted, and that mainly the opposing sectors want to silence, based on the image of the persecuted, molded in the ministerial context of Benedict XVI's papacy. Then, during the election period, the priest feeds the pace of the persecution reasoning against the candidate Bolsonaro, through Christianity, reinforcing what Bolsonaro himself says: "be like Christ, who suffered attacks from all sides, but still won" (Bolsonaro 2020a).

With the scene, as following, this pace feeds the intense "war of the gods" in which he nurtures Bolsonaro's later administration policy. As much as so that Bolsonaro repeatedly argues that "everyone stands up to silence us, everyone wants us be silent, but they will not (...) I am like Christ, persecuted” (Bolsonaro 2020a).

\section{The War Against Gramscism}

The third "mediatic scene" (Lévy 1999) and political action architected by Paulo Ricardo was quite more recent. Already under the Bolsonaro administration, and in the middle of the pandemic, the video once again circulated: "The imbecialization of the country" (Paulo Ricardo 2017). This video is another important material, when the priest deals with the issue of gramscism (Ricupero 2010, 76-94). For the Brazilian ultraconservative sector, gramscism would be a "gathering of thought that performs the revolutionary processes of taking liberal thought in the uses and customs, communist, popular," an antagonist who moved "against conservative thinking, against the right and the faithful Christian family. It is against them that a perverted world elite struggles daily to take over conservative spaces" (Ricupero 2010, 90).

On the subject, in the video, the priest seems to be giving a lecture when he returns, again, to the use of persecutory reasoning, mocking the tendencies of "cultured" norm and the "popular language" as being one root of the social problems that are experienced in Brazil and in the World (Paulo Ricardo 2017). He does this by assuming a generic accusation, blaming teachers for passing on to students "a social text, with the pretension of making politics, when it pays to teach Portuguese" (Paulo Ricardo 2017).

In his speech, with no data or sources being quoted, he accuses teachers of trying to outline a silent process, starting from the classroom to inculcate the politicization of children and adolescents. By asserting this, he blames the Professorial class for causing a "slow and gradual imbecialization of a nation" (Paulo Ricardo 2017), and they do this to establish a little critic thinking and thereby facilitate the "leftist" domination of the country. The priest triggers a "conspiracy theory" (Teixeira da Silva 2020a, b) that teachers build a communist collusion when they distinguish 
"cultured" norm and "popular language" (Ricupero 2010, 90). In this accusatory political action, he indicates that "instead of teaching Portuguese, they are learning a Marxist booklet. This helps a lot, because after all, if I want to implement socialism, if I want to dominate a society, nothing better than dominating a language class" (Paulo Ricardo 2017).

The priest dressed in religious clothes (then equipped by the priestly symbolic) accuses the category of teachers in the first grades of purposefully causing what he calls "nation imbecialization" (Paulo Ricardo 2017). In doing so, he builds an accusation "typical of Brazilian elites who prefer to accuse the Professorial sector of collusion in order not to recognize the importance of the sector for the construction of the country" (Massenberg 2007, 91).

In the video, he stresses the role of educators by weaving accusations typical of conspiracy theories, a so important tangle in the wars of the gods. The priest's speech is related to the studies proposed by the ultra-right intellectual Olavo de Carvalho, as highlighted by Debora Massenberg 2007. Father Paulo Ricardo follows the Olavista bulla, by indicating that the teachers "do not want you to learn anything, that you study anything, to practise, the way they want it, this is Gramscism in practice!" (Paulo Ricardo 2017). The priest appeals to Olavo de Carvalho's conspiracy theory discourse, which theorizes about the "Foro de São Paulo, as an organization created by Lula and Fidel Castro, based on Marxism and the liberalisation of customs, which uses Gramsci as a method of taking mentalities" (Massenberg 2007, 72).

Paulo Ricardo goes on saying, "even if you have not heard of Antônio Gramsci you are a profound connoisseur of Gramsci (...) a practical connoisseur, because you have been a victim of him" (Paulo Ricardo 2017). Following the same steps as Olavo de Carvalho, the priest blames basic education teachers for building a "leftist" ideology, based on Gramsci, called "new world order" (Paulo Ricardo 2017) which is linked to the "Foro de São Paulo, Lula and Fidel" (Massenberg 2007). This is the deduction built on this political action involved in a persecutory tone, full of a "path of disinformation," as Francisco Teixeira da Silvia (2020) writes. Thus, the priest triggers a common line of reasoning in current Brazilian conservatism (Massenberg 2007), which despises teaching and stands out from the discourse of "cultural war" based on the reasoning that there is a worldwide plot against "the truth of the Christian family" (Paulo Ricardo 2017).

So, within the political action in the form of "mediatic production of networks" (Lévy 1999), Father Paulo Ricardo verbalizes a linguistic point of cultured or colloquial norm into an "extreme cultural war, which, for him, is a sign of atheism, of communist world in which took account of Brazil" (Massenberg 2007).

\section{The Pandemic and the Fact of "Not Tempting God"}

Following the sequence, another political action from the priest was recorded during the Covid-19 pandemic period, and it was called "The lying flat church in the face of a virus?" (Paulo Ricardo 2020a-on March 22, 2020). That already was the President Jair Messias Bolsonaro's second year in office, and the priest 
starts to comment theologically on the world event of the pandemic. It is his first theological production on the impact of Covid-19, built on the first cases in the region where he has a pastoral role in the region of Mato Grosso. The reason for its production was the Vatican ordering to close the parishes in the face of the pandemic catastrophe and, then, he opens the video asking: "Has the Church lost its faith? (...) our bishops being cowards, by canceling and depriving souls of the comfort of the sacraments?" (Paulo Ricardo 2020a).

Hence, Paulo Ricardo, in the mediatic political action, in the middle of the Bolsonaro's government and Covid-19 pandemic, opens a series of questions about the pandemic outbreak. His questions are based on a distinction that concerns the Vatican Council I discussions and the debates that shaped the council which deals with the issue of fideism. Fideism is a doctrine in which it understands that "metaphysical and moral truths, as existence of the divine, are unattainable to human reason, only being understood through faith" (Azevedo 2003, 19). Fideists are not concerned with arguments that aim to support their faith in the divine, without rationalization, and at the same time, they contradict themselves in seeking the reason to expose their thought. In this sense, Demi Azevedo indicates that fideism "fears reason: if it is practise as a type of blind faith" (Azevedo 2003, 90).

The debates carried out by Pope Pius IX indicate fideism as a characteristic feature that understands that religious points cannot be justified by means of arguments or evidence, but just by faith (Azevedo 2003). Then, the priest returns to the central reasoning for Brazilian ultra-catholic sector, starting with Pope Pius IX (linked to the First Vatican Council), leaving aside the renewal of Catholic theology that occurred with the Second Vatican Council. Upon resuming Pius IX, the priest says that the problem is not only with the fideist affirmation (which is "only faith") or "rationalism (...) only reason" in the context of the pandemic. The question is whether in the face of this plague that, based on faith, with prayers and supplications, one can "compel God to interfere in human history with the opening of parishes" (Paulo Ricardo 2020a).

In the "mediatic political production" (Lévy 1999, 70), the priest affirms that the issue of building a series of devotional actions can "compel God to perform a miracle" (Paulo Ricardo 2020a). Thus, he uses the New Testament text, the narrative that the devil did with Jesus in the fragment of Matthew 4 and Luke 4,1-13. He summarizes as follows: "opening the doors of parishes (...) is to tempt God. Because you are forcing God to do the miracle!" (Paulo Ricardo 2020a). It follows the reasoning stating that to be catholic "and fideistic? (...) is craziness!". In this sense, in terms of the history of Christian theology, the priest is concerned with closing the parishes "so as not to compel God to do miracles" (Paulo Ricardo 2020a). He categorically affirms he will not open the Church: to "not tempting God-as the devil did according to the narrative of the gospels" (Paulo Ricardo 2020a).

Therefore, in the midst of the political social clashes caused by the Covid-19 pandemic, the priest does not directly indicate the key issue of science in favor of social isolation, in order to avoid agglomerations to reduce contagion. In this political action, pro Bolsonaro's positions, celebrations must be prevented so as not to force the divine to perform miracles. 


\section{The Pandemic and the Original Sin}

The fifth "political action" (Rosanvallon 2015) separate media, from this small political trajectory of the priest, took place on April 1, 2020, close to Easter, when he released another video of the series about Covid-19. In the material, he tries to answer the question "If Covid-19, and other plagues, are punishments from God?" (Paulo Ricardo 2020b). In this action, the material follows the argumentative line of Bolsonaro's government indicating that one should think about the economy and not make a total social isolation within society (Py 2020a). Thus, it continues to raise some important questions for the history of the church: "if he (God) is a kind and compassionate father, how would he allow such evils on the innocent?" (Paulo Ricardo 2020b).

He opens his argument with the following theological construction: "the problem of humanity is sin" (Paulo Ricardo 2020b), as the Bolsonaro summit has already argued (Bolsonaro 2020b). The priest affirms that the problem of the thousands of dead "in the world is sin," dealing with all socio-historical reality under the maxima transcendental, something very common to fundamentalist Christian religion path. With this argument, he stresses that it is "sin that is killing people" (Paulo Ricardo 2020b). Therefore, from the video, he derives a political action in support of the "war of the gods" (Lowy 2000), important for the Bolsonaro government, by exposing a common theological understanding in the ultraconservative Christian universe as a political argument.

In other words, the priest turns the human problem into a theological judgment. This reasoning follows when he evokes: "Our Lord Jesus Christ suffered on the Cross, not because of his sins, but for ours. (...) Suffering is a sign of our sins, of original sin, of the sin we do" (Paulo Ricardo 2020b). By this statement, he radicalized Christian dogmatism, saying "suffering and death are signs of the original sin of humanity" (Paulo Ricardo 2020b). For this he uses a typical trick of all the great monotheistic religions (Weber 1988), by indicating, "it is not any sin, but rather, the original sin that has tainted all humanity" (Paulo Ricardo 2020b).

The production of the video occurred with exponential increase in deaths by Covid-19, in 2020. So, in this context, and the priest evokes the idea of original sin, more seemingly being part of a hatred for socio religious plurality (Py 2020a). It follows the reasoning stating the current suffering to Jesus martyrdom when he says: "What I am suffering is nothing, in face of what he suffered for me on the cross" (Paulo Ricardo 2020b). It adequates "all suffering on the same bias of Jesus' suffering, on the suffering Jesus would have been exposed to at the crucifixion" (Boff 1974, 113), just as Leonardo Boff points out, being something typical of exclusivist Christianity. At the end of the video, he goes back to President Bolsonaro's vocabulary, calling the pandemic "collective hysteria" (Paulo Ricardo 2020b).

For him, as in common to the Bolsonaro's administration, even with the mark of thousand of deaths in Brazil, the Covid-19 pandemic is part of the "collective hysteria" and serves as "divine pedagogy" (Paulo Ricardo 2020b). In the priest's line of reasoning, what is happening are just small trials on the "suffering that will come to the church in the future" (Paulo Ricardo 2020b). It is this reasoning that makes the choice to appeal to the history of the church and indicates "the suffering 
that is happening is only an indication of the final suffering" (Paulo Ricardo 2020b). Therefore, in this political action, Paulo Ricardo exposes his Christian conservatism by affirming that the pandemic is just a "training of what we will go through in the future and that only a few will survive" (Paulo Ricardo 2020b). In the same way Bolsonaro indicates the survivors of this "war of the gods" when he says that they are "men and women elected by God and by the holy Roman Catholic Church that will make the Brazilian nation better" (Bolsonaro 2020b).

\section{Covid Is for Cleansening}

The sixth and last mediatic political action (Rosanvallon 2015) of this short "individual trajectory" (Lévy 1999), of Father Paulo Ricardo from 2013 up to 2020, we find another theologization of immanent issues. This last material, the only one that is not found in the form of a video, but is in the form of a writing that was posted on July 15, 2020, on his personal website published in the form of an article entitled: "The Pandemic and the Four Horsemen of Apocalypse" (Paulo Ricardo 2020c). In the article, he deals with the issue of diseases, plagues, cyclones, and earthquakes and political and social wars that have been going on since the beginning of 2020 . As referred, he develops on the sign of the Gospel of Matthew 24:8, "in fact, it will raise nation against nation and kingdom against kingdom. There will be famines and earthquakes in several places. All of this is the beginning of the pain."

That being said, the priest seeks to give the theological bias to the article based on the Gospel of Matthew, indicating, "Covid-19 would be only the beginning of humanity problems" (Paulo Ricardo 2020c). As referred, he takes the focus off the Bolsonaro administration, and at the same time, he deals with "the plagues that are the beginning of the end of the world to come, that he is, in fact, a training for the near future" (Paulo Ricardo 2020c).

In this "mediatic play" (Lévy 1999), the priest then evokes the idea of church history's beginning of the "Great Tribulation" (Paulo Ricardo 2020c) and thus feeds the Christianity conservative sector's reasoning in which it is part. Who summarizes the maxim of this thought is Ruben Alves, when writing about some interpretations of the Apocalypse, "that only a few people will be saved, elected who enjoy the face of the divine, who is a God from above, despotic who penalizes the rest of all humanity" (Alves 1975, 41). With that, in his political action (Rosanvallon 2015), he connects in the same reasoning the Gospel of Matthew, the plague, and the cleansing. Thus, he summarizes in his article's central argument: "The 'plague', 'hunger' and 'war' are biblically linked to the cleansing, purification, that men need to go through" (Paulo Ricardo 2020c).

In his ultraconservative Christian thesis, based on theological exclusivism for a socio-biological eugenic policy (Py 2020a, 17) so important for Bolsonaro's conservative management. The priest theologically bases the government in the face of the pandemic, evoking a Christian idea of reaffirming the triumph of some "those separated by God" (Alves 1975, 61), those who will be the "pure" through punishment of the Covid-19 plague. 
Along these lines, "in this non-electoral, but supportive political intervention" (Rosanvallon 2015, 61), it helps to weave Bolsonaro's "theology of authoritarian power" (Schmitt 1988) when shortly after the speech of the priest's post, the president himself stated that he learned in (Catholic) Christianity that "the pandemic will also make us better, in the end God will triumph" (Bolsonaro 2020b). Hence, it is said that the authoritarian policy of the current president is connected to his articulating priest, who has been formulating subsidies for the construction of Bolsonaro's Christofascist government. In this case, the priest's ultraconservative theology supports the "war of the gods" policy, so dear to the government, that it recognizes the social importance of deaths in the midst of a pandemic.

The priest himself admits that, when he addresses that the formula of plague, hunger and war, in the Bible, is linked to the purification that "men must undergo" (Paulo Ricardo 2020c). He emphasizes that the martyrdom of all humanity occurs because of "sin" - as further indicated (Paulo Ricardo 2020c) — and then reveals the importance, in Christian terms, of the three tragedies: plague, famine, and war.

Possessing the "mediatic material" (Lévy 1999), the priest admits that certain cataclysms that occur in humanity serve for "purification, (cleansing)" and the line that follows Bolsonarism and the consequences of the Covid plague (Py 2020b). In this case, Paulo Ricardo maintains the argument that since biblical societies, people who survive major disasters are those who are not exposed to disease, do not go hungry, or do not go to war. Therefore, the Christian sentence of the priest is, above all, blind to social issues or, rather, does not recognize the importance of the social context for theological evocation.

Something in common, among the ultraconservative sectors, that emphasizes theological phrases at the expense of other specifications of life. Therefore Father Paulo Ricardo justifies what Judith Butler affirms about the eugenic modulations intrinsic to Christian societies.

\section{Latest Forewarnings}

In the article, we sought to address an important person belonging to ultraconservative Catholicism, Father Paulo Ricardo, from his most recent individual trajectory (between 2013 an 2020) through a set of "political actions" (Rosanvallon 2015) of the priest with selected "mediatic scenes" (Lévy 1999) that demonstrate "not only an electoral expansion of political interventions" (Rosanvallon 2015, 65). Then, the priest's most recent political trajectory was traced through videos and articles that serve as ideological material for the Bolsonaro government.

Based on the renewed political history developed from René Rémond (1999), we sought to trace the figure of the priest and how he is currently coloring the construction of the figure of Bolsonaro with conservative Catholic bias, the builder of a "theology of authoritarian power" (cristofascista - Py 2020a), full of signs of a god from above, despotic.

Hence, with the article, Father Paulo Ricardo was signaled as the articulator of the rise of Bolsonarism to power, helped to mobilize a series of important themes for management: the conspiracy theory that puts teachers as the tip of Gramscianism in 
Brazil; he accuses the left political ideology trying to silence Bolsonaro; defends the armament of the Brazilian population; affirms that the pandemic is just a little grip and that a collective hysteria with this "little grip" has been occurring (Bolsonaro 2020b). However, his denser "political production" (Rosanvallon 2015) links conservative Catholic theology to the pandemic. The priest as an ultra-Catholic mobilizer writes the complex formula that for the divine, a test (such as the pandemic) is not only intended to teach, but, above all, to purify the Brazilian nation.

Therefore, the connection channel between the priest and the Bolsonaro's close circle dome is dense, in such a way that his "media productions" (Lévy 1999) were repeatedly posted on the social networks of Bolsonaro's elites, helping the cybernetic construction of the current Brazilian Christofascism. Thus, the most recent priest's “individual trajectory" (Lévy 1999) is a key part of Bolsonaro's policy, operating in a different way from Silas Malafaia, a resounding evangelist. Nor does he acts in a technological way like Baptist pastor Valandro Junior, but, rather, he deals with themes dear to Bolsonaro, following the script of the Catholic formation, that is, with few gestures, always restrained expressions, and not changing the tone of his voice. In this way, the priest becomes a backbone for the construction of Bolsonaro government, in which he despises science in favor of a fundamentalist and conservative theology.

\section{References}

Almeida, Ronaldo (2019) Bolsonaro presidente: conservadorismo, evangelismo e a crise brasileira. Novos estudos Cebrap: 185-215

Alves, Ruben (1975) O enigma da religião. Petrópolis, Vozes

Azevedo, Demi (2003) Desafios estratégicos da Igreja Católica. Lua Nova, 60

Benjamin, W (2013), O capitalismo como religião, São Paulo, Boitempo

Butler J (2004) Undoing gender. Routledge, Nova York

Boff, L (1974) Jesus Cristo libertador. Petrópolis, Vozes

Bolsonaro, Jair Messias (2020a) Instagram 03 junho de 2020, https://instagram.com/jairmessiasbols onaro. Acessed 03 junho de 2020

Bolsonaro, Jair Messias (2020b). Pronunciamento do presidente da República. Jair Bolsonaro (08/04/2020), Youtube, 8 de abril de 2020, https://www.youtube.com/watch?v=x04OKkxT2Tc. Acessed 03 de junho de 2020

Bourdieu, P (1996) As ilusões do uso biográfico. In: AMADO, J; FERREIRA, M. (Org), Usos e abusos da história oral. Rio de Janeiro: FGV: 115-122

Gagnebin, Jeanne Marie (2014) Limiar, Aura e Rememoração. São Paulo, Editora 34

Gramsci A (1982) (1982) Os intelectuais e a organização da cultura. Civilização Brasileira, Rio de Janeiro

Lévy, Pierre (1999) Cibercultura. São Paulo, Editora 34

Lowy, Michael (2000) A guerra dos deuses. Petrópolis, Vozes

Mbembe, A (2014) Crítica da razão negra, São Paulo, Antigona

Massenberg, Da (2007) A direita saiu do armário: a cosmovisão dos formadores de opinião dos manifestantes brasileiros, Sociedade e Estado, v.32 (n.3)

Py, F (2020a) Pandemia cristofascista. São Paulo, Recriar

Py F (2020b) Bolsonaro's Brazilian Christofascism during the Easter period plagued by Covid-19. International Journal of Latin American Religions 4:318-334

Paulo Ricardo (2011) A igreja e o desarmamento, YouTube, https://padrepauloricardo.org/episodios/aigreja-e-o-desarmamento. Acessed 03 junho de 2020 
Paulo Ricardo (2018) Padre Paulo Ricardo se pronuncia sobre o atentado contra Bolsonaro e o vídeo viraliza na web, Youtube, https://www.youtube.com/watch?v=qvNe82soUEE\&list=LLkZHGIl1H FSKQapVFB59m6g\&index=1411. Acessed 17 junho de 2020

Paulo Ricardo (2017) Marxismo cultural e Revolução Cultura, You Tube, https://www.youtube.com/ watch? $\mathrm{v}=\mathrm{EQNSoNR}$ jLE. Acessed 08 Jun 2021

Paulo Ricardo (2020a) A igreja prostada diante de um vírus?, Youtube, Acessed 29 de junho de 2020

Paulo Ricardo (2020b) "Se o Covid-19, e outras pestes, são castigos de Deus? Indagou se seriam castigos de Deus?", Youtube, https://www.youtube.com/watch?v=2kyUxZkFYM0\&t=910s. Acessed 30 de junho de 2020

Paulo, Ricardo (2020c) Pandemia e os quatro cavaleiros do apocalipse, pagina pessoal, https://padrepaulo ricardo.org/blog/a-pandemia-e-os-quatro-cavaleiros-do-apocalipse. Acessed 30 de junho de 2020

Rémond, R (1999) O retorno do político. In: CHAUVEAU, A.; TETARD, P. (Org.). Questões para a história do presente. Bauru, Edusc

Ricupero, B (2010) O conservadorismo difícil. In: FERREIRA, Gabriela Nunes; Botelho, A (orgs.). Revisão do pensamento conservador: ideias e política no Brasil. São Paulo, Hucitec-FAPESP: 76-94

Rolland, D (2004) Internet e história do tempo presente: estratégias de memória e mitologias políticas, Tempo, n. $16(8)$

Rosanvallon P (2015) Le Bon Gouvernement. Éditions du Seuil, Paris

Schmitt C (1988) Théologie politique. Gallimard, Paris

Silveira EJS (2019) Padres conservadores em armas: o discurso público da guerra cultural entre católicos. REFLEXÃO (PUCCAMP) 43:289-309

Sölle D (1970) Beyond Mere Obedience: Reflections on a Christian Ethic for the Future. Augsburg Publishing House, Minneapolis

Sölle D (1999) Against the Wind: Memoir of a Radical Christian. Minnesota Fortress Press, Minneapolis

Teixeira da Silva FC (2020a) Máscara, Máscaras: Pandemia e Homossexualidade na Novilíngua do Bolsonarismo. Cadernos Do Tempo Presente 11:01-101

Teixeira da Silva FC (2020b) Novas tensões Geopolíticas hoje. Cadernos de Estudos Estratégicos: 29-49

Weber, M (1988) A ciência como vocação. São Paulo, Cultix

Zeferino J, Andrade R (2020) A tradução fundamentalista: equivalências hermenêuticas entre teologias exclusivistas e modelos democráticos. Horizonte-Revista De Estudos De Teologia e Ciências Da Religião 18(57):1050-1169

Publisher's Note Springer Nature remains neutral with regard to jurisdictional claims in published maps and institutional affiliations. 